\title{
PLACE OF ADMINISTRATIVE SUPERVISION IN THE ACTIVITIES OF THE EXECUTIVE POWER OF UKRAINE
}

\author{
Denysova A. V.
}

\section{INTRODUCTION}

The constitutional and legal content of the executive power is a result of the prescriptions of the Constitution of Ukraine, which provides for the separation of state power into legislative, executive and judicial branches. The purpose of separation is to ensure the rights and freedoms of man and citizen, political stability. Separation of state power is the basis of the deconcentration of power, which excludes of excessive concentration of power in individual state bodies, dangerous for the public freedom, ensures "preventing the appropriation of the completeness of state power by one of the branches of power". Separation of state power acts as a principle, the basis of the functioning of the mechanism of the state and is implemented in the activities of the relevant bodies and they are the legislative, the executive and the judiciary, each of which performs separate tasks and functions, but within the sole purpose of the state power, which involves interaction between them. Separation of state power does not preclude interaction between public authorities, including the provision of necessary information, participation in the preparation or consideration of a particular issue, etc. Such interaction should be permermed taken into account the requirements of the Constitution of Ukraine, according to which state authorities are obliged to act on the basis, within the powers and in the manner provided by the Constitution and laws of Ukraine.

This means unity in the content of state power, and the constitutional principle of separation of powers is a theoretical constant, which allows to build a state mechanism and organize its functioning, which means in organizational terms the realization of state power through certain types of state bodies. The powers are distributed among them in such a way that they are independent in exercising their competence within the limits established by the Constitution and interact with each other by means of certain levers of mutual "restraint" and "counterbalance".

Scientists note that not only power is shared, but the functional and structural mechanism of its implementation. In one case, separation of powers means the separation of the main functional activities of the state lawmaking, enforcement and justice, and in the other that the organizational structure of the state as a set of different types of state bodies and they are legislative, executive and judicial (these are only the main types), with their inherent competence which is a set of state-power powers 


\section{The essence of the executive power in Ukraine}

The peculiarity of executive power among the branches of state power is manifested in its focus on the implementation of laws and other normative acts of the state, as well as in the practical application of all levers of state regulation and management of important processes of social development. The decisive focus of the executive is to assert and secure human rights and freedoms and is recognized by the Constitution of Ukraine (Article 3) as "the highest social value" ${ }^{1}$.

The constitutional and legal nature of the separation of state power determines the need to distinguish the following features of the executive power:

- inalienability in the separation of state power;

- is one of the functional activities of the state - law enforcement;

- is a component of the functional and structural mechanism of exercising state power;

- is a component of the organizational structure of the state in the form of a system of bodies of executive power; power ${ }^{2}$.

- organizationally represented by the entities, holders of executive

The constitutional and legal content and organizational form are reproduced in the listed features of the executive branch. This means that the principle of separation of powers as the basis for the functioning of the mechanism of the state is organizationally represented by the system of executive bodies. At the same time, the essence of the executive power in the light of the principle of separation of state power is characterized from the point of view of implementation of one of the functional activities of the state and it is the implementation of laws. The executive nature of power, which determines the content of the executive power, causes the expansion of the executive power and it is beyond the system of executive bodies, which allows to indicate the exercise of executive power by its holders who are authorized entities.

In this connection, scientists point to the need to distinguish between public administration and executive power, noting that some of the functions of public administration are exercised outside the executive power, but at the same time, some of the functions of executive power are exercised outside of public administration. This means that public administration can be carried

\footnotetext{
${ }^{1}$ Виконавча влада і адміністративне право/ За заг.ред. В.Б. Авер'янова. К.: Видавничий Дім “Ін Юре”, 2002. 668 с.

2 Денисова А. В. Сущность и содержание базовых категорий административного права: отдельные проблемы определения / А. В. Денисова // Legea si Viata. - 2017. - № 3/2 (303). C. $57-60$
} 
out not only within the system of executive bodies, but also when organizing the activities of enterprises, institutions, organizations of state ownership. The executive power is also exercised in the case of delegation of powers to the bodies of local self-government. Thus, public administration and executive power are regarded as legal phenomena, and the corresponding categories indicate the peculiarities of their manifestations in the organization of the functioning of the mechanism of the state. These legal phenomena are reproduced in the competence of the entities of the state administration and the executive power. The constitutional and legal content of the executive power determines its legal significance, which is wider in content and essence than the state administration.

The essence of administrative activity is revealed in the research of scientists who dealt mainly with the problems of legal protection and the activity of law enforcement agencies. The term "administrative activity" refers to the imperative, state-governmental, executive-administrative activity of law enforcement agencies, which concerned both management and issues of application of administrative-jurisdictional powers.

It is advisable to mention the scientific approach of Zolotarova N.I., who points to the wider meaning of the notion of administrative activity of the authorities compared to the concept of the executive. The researcher emphasizes the difference in the entities of administrative activity and executive power. Thus, the executive power is exercised only by the bodies of this branch of power and special institutions, and powers to exercise the functions of the bodies of the executive power are delegated to them. The number of entities of administrative activity, which are called administrative by the researcher, and they are regulated by the norms of administrative law, it is wider, because it is carried out not only by executive bodies, but also by courts, prosecutor's offices, the Secretariat of the Verkhovna Rada of Ukraine, and the Presidential Administration. These entities carry out organizational activities related to the performance of administrative functions ${ }^{3}$.

However, Zolotarova N.I. determines the relationship between the administrative activity of the authorities and the executive power, using terms whose content needs clarification and concretization. In particular, the above refers to terms such as "organization", "institution", which leads to some inaccuracies in the definition of the subjective composition of administrative activity and executive power. That is why this approach of the researcher, although it is interesting, is not unquestionable.

3 Золотарьова Н. І. Співвідношення виконавчої влади та адміністративної діяльності / Н. І. Золотарьова // Вісник Національного технічного університету “КПІ". - 2011. № 1 (9). - C. 45-54. 
Another approach is to identify the nature and content of administrative activity that implies its focus on the exercise of citizens' rights and freedoms in the field of governance. Among the features of administrative activity, the executive and administrative nature is indicated, the entities are public authorities, regulated by the rules of administrative law ${ }^{4}$. Revealing the essence of the executive nature of the activity of executive bodies, Melnyk A.F. noted that it is practical implementation of legislative acts, operational and dynamic management of economic and social spheres, as well as statepolitical activity (defense, security, customs and tax). According to the researcher, the administrative character of the state-administrative activity is to issue executive bodies of decrees, orders, orders, instructions, rules and other by-laws, which allows to ensure compliance with the norms and principles of the Constitution of Ukraine, laws, other normative acts and effectively manage the branches of economy and socio-cultural sphere ${ }^{5}$.

The definitions mentioned above and characteristics of administrative activity are presented by researchers in the field of public administration, but their work is appropriate even in the case of their use in scientific developments in administrative law. The theoretical novelty of this approach is to take into account the primacy of the rights and freedoms of citizens in this activity, which allows to determine the main purpose of administrative activity of bodies of executive power the realization of citizens' constitutional rights and protection of their rights and freedoms.

Thus, it is expedient to define administrative activity as regulated by norms of administrative law specific, executive-administrative, subordinate, state-government purposeful activity of the authorized bodies of executive power (officials) in the exercise of the constitutional rights of citizens and protection of their rights and freedoms.

Among the features (signs) of administrative activity it is advisable to emphasize:

- executive and administrative character, which is manifested in the enforcement activities of authorized entities, the peculiarities of which are to establish a legal obligation to act clearly within the limits and on the basis of the rules of the current legislation in order to perform the tasks and functions corresponding to the legal status;

${ }^{4}$ Гробова В. П. Адміністративний аспект державного управління / В. П. Гробова // Актуальные проблемы права: теория и практика. Сборник научных трудов. - 2010. № 18. - С. 298-304.

5 Державне управління : навч. посіб./ [Мельник А. Ф., Оболенський О. Ю., Васіна А. Ю., Гордієнко Л. Ю. та ін..] ; під ред. А. Ф. Мельник. - К. : Знання-Прес, 2003. $343 \mathrm{c}$. 
- subordinate nature of administrative activities, which means its focus on the implementation of the law;

- state-governmental character, which means performing administrative activities on behalf of the state and performing the functions of the state. At the same time, the authorized entities act on behalf of the state and their activities are not individualized;

- accountability and control as characteristic features (features) of administrative activity, the specificity of which is determined, first of all, by the imperative nature of the activity of executive bodies.

In revealing the content of accountability, Sinkova A.M. described it as a legal category, which is considered in the current legislation, primarily from the point of view of the form of management, which is a prerequisite for ensuring socio-political stability and making optimal decisions. The researcher defines accountability as a tool for creating information flows and defining communicative interactions between executive bodies, as well as between the system of executive authorities and the external environment ${ }^{6}$.

Taking into account the scientific approach Synkova O.M. on the essence of accountability allows to distinguish the administrative nature of administrative activities. This approach does not identify management and administrative activities. Being legal phenomena of different order of administration and administrative activity they are correlated as general and special. In this case, management is viewed from the standpoint of the general legal phenomenon, as opposed to administrative activity, which reproduces the specific purposeful nature of management. Along with this approach, it is advisable to talk about the procedural aspect of the relationship between management and administrative activity, according to which administrative activity should be indicated as a component of management activity, taking into account the difference in the entities of implementation. If administrative activities (according to the existing theoretical experience) are connected with executive authorities, then administrative activity is carried out by a wider range of entities.

In the case of a wide approach to defining the nature and content of management and administrative activity, it is appropriate to note their identical nature, especially given the designation of the term "administrative" purposeful influence on a particular object.

Therefore, characterization of the content of management and administrative activity can be implemented in aspects of material and

\footnotetext{
${ }^{6}$ Синкова О.М. Підзвітність в системі органів виконавчої влади: організаційно-правові проблеми: дис. ... д.ю.н. 12.00.07 / Синкова Олена Михайлівна / Інститут держави і права ім. В. М. Корецького НАН України. - К., 2011. - 400 с.
} 
procedural by "wide" or "narrow" approaches. The material aspect involves the characterization of management and administrative activity as legal phenomena. Procedural is a type of activity (a set of sequentially performed deliberate procedures) of authorized entities. The "wide" and "narrow" approaches are a logical extension of the procedural aspect of the nature and content of management and administrative activity.

The consideration of the procedural aspect in the characterization of administrative activity allows to distinguish organizational and jurisdictional types of administrative activity. Organizational refers to the formation of the state apparatus, administrative decisions, the implementation of logistical operations, the performance of office functions, personnel, information support, etc. Jurisdictional administrative activity concerns the application of measures of administrative compulsion, bringing to administrative and disciplinary responsibility, administrative appeal.

According to the directions of influence, administrative activity is divided into internal organizational (internal) and external organizational (external). Internal organization refers to the ordering of relations within the structure of the system of executive bodies: personnel, information, resource and other types of security. External organizational administrative activity is the main activity of executive bodies aimed at fulfilling the tasks and functions assigned to them by the current legislation. Administrative-supervisory activity is a part of the external organizational activity of executive bodies.

At the same time, it is worth to mention about the latest developments on the problem of dissemination of the dispositive method in administrative law. Thus, according to Riabchenko O.P., in the economic sphere, the means and measures inherent in the dispositive method of public-legal regulation of relations should be developed, which means establishing the legal possibility of alternative choices by participants of these relations of behavior within the law. Such legal possibility is realized, in particular, in permits, administrative contracts, administrative services that ensure social freedom and human activity, the implementation of the principle of "what is not prohibited by law" is allowed? .

This approach allows you to extend the nature of administrative activity, introducing the principles of dispositiveness. Mentioned information determines the need to establish such a feature of administrative activity as the legal possibility of applying the dispositive method in order to streamline public-legal relations.

7 Рябченко О. П. Концептуальні проблеми застосування диспозитивного методу публічно-правового регулювання відносин у сфері економіки / О.П. Рябченко: наукова доповідь. - К.: Логос, 2013. - 40 с. 
Taking into account mentioned information, we can distinguish the following features (signs) of administrative activity:

- is executive-administrative;

- is by-law;

- has a state-power character;

- is accountable and controlled;

- has the legal possibility of applying the means and measures of influence inherent in the dispositive method ${ }^{8}$.

The listed features (signs) of administrative activity reflect its executive nature, which allows to speak about its compliance with the executive activity, which is carried out by the executive power bodies, authorized entities.

It should be emphasized that there are no contradictions in establishing the features of administrative (executive) activity of the state-governmental nature and the availability of a legal possibility of applying the principles of dispositiveness, given that the latter feature forms a modern perception of state-governmental activity as such, within which administrative services may be provided, administrative contracts may be concluded.

Thus, in the categories "executive power", "public administration", "administrative activity" are their executive nature and state power. Even if there is a legal possibility of using the means and measures inherent in the dispositive method of legal influence, the authorized person for their application acts for the purpose of performing state tasks and functions and is not individualized. The doctrine of public administration needs to be substantially updated, taking into account the tendencies to modernize the forms and methods of administrative and legal influence characteristic of the dispositive method of public legal regulation: an administrative contract, an administrative service, the need for the development of which is objectively conditioned by the social essence of social transformations. Provided they are taken into account; one can anticipate the convergence of the doctrine of public administration into public administration. The modern approach to defining the essence of the category "public administration" allows to speak about its narrower meaning in comparison with the categories "executive power" and "administrative activity".

The search for a single category, which should take into account theoretical principles, on the one hand, and the executive nature of the activities of authorized entities, has recently led to the active use of the term "public administration" in scientific research.

8 Денисова А. В. Сутність адміністративної діяльності щодо здійснення нагляду органами виконавчої влади та їі місце у виконавчій владі / А. В. Денисова // Актуальні проблеми держави і права. - 2017. - Випуск 79. - № 79. - С. 46-50. 
According to scientists, public administration reveals the main directions of purposeful activity of entities of power over the performance of administrative duties ${ }^{9}$. In essence, this approach can be called wide, taking into account the fact that it covers all the activities of entities vested with powers that carry out administrative content obligations. However, taking into account the substantive ambiguity (that is, the lack of a unified scientific approach to determine the essence) of the term "entity of authority", that was repeatedly noted by scholars who analyzed the problems of judicial administrative jurisdiction and ambiguity of meaningful content in the category administration is inappropriate.

The scientific approach of Vitvitskyi S.S. is interesting, the scientist proposed to systematize the activities of public administration and distinguish three types of it: 1) managerial (organizational, as well as public service); 2) control; 3) administrative and jurisdictional. The researcher, relying on scientific approach Tymoshenko K.O., stated that administrative-judicial activity can be considered from the standpoint of guarantees of legality and restoration of the violated right, which is carried out by authorized entities public administration and courts (administrative courts) ${ }^{10}$.

This approach can be accepted in case that the public administration (whose activity is called public administration) is performed by the state executive bodies, local self-government bodies in the exercise of the delegated powers of the executive power. Right this approach to the definition of public administration is suggested by Vitvitskyi S.S. At the same time, supervision is not singled out as a separate activity of public administration.

Approach presented by Vitvitskyi S.S. can be applied to determine the place of administrative oversight among public administration activities (ie, public administration). Considering the nature of administrative oversight does not allow it to be attributed to control or administrative and jurisdictional activity, especially considering the fact that supervision combines both positive and negative (extrajudicial) administrative activities. Taking into account mentioned information, it is appropriate to note that the administrative oversight carried out by the executive authorities is covered by the control and administrative-jurisdictional activities of the public administration. The term "public administration" means the bodies of state executive power and local self-government bodies in the part of exercising their delegated powers of executive power.

${ }^{9}$ Курс адміністративного права України: підручник / В. К. Колпаков, О. В. Кузьменко, І. Д. Пастух, В. Д. Сущенко [та ін.] / за ред. В. В. Коваленка. - К.: Юрінком Інтер, 2012. $808 \mathrm{c}$.

${ }^{10}$ Вітвіцький С. С. Контроль діяльності публічної адміністрації в Україні: теорія і практика [монографія] / С. С. Вітвіцький. - Дніпропетровськ: Дніпропетровський державний університет внутрішніх справ, 2015. - 362 с. 
The approach of introducing the term "public administration" presented by the researchers is not well established and needs further scientific analysis. Thus, according to the meaning of the word "public", the term "public administration" should cover not only the activity of executive bodies, but also the activity of all public authorities, local self-government bodies, public and international organizations.

Appeal to legal encyclopedic publications gives the opportunity to distinguish the legal meaning of the term "public", which follows from the content of the terms "public law", "public-legal relations", "public interest".

Public law is the system of legal rules governing relations in the sphere of public authority. The entity of regulation of public law is the structure and functioning of the state, its institutions, institutions of civil society, human and civil rights and freedoms, the relationship between the individual and the state in the field of public order, the mechanism and levels of self-government, consolidation of public interest in the system of finance and labor, the basics of the legal system, lawmaking and enforcement, principles, norms and institutions of interstate relations and international organizations. Regarding public-law relations, it is stated that such are public relations that arise between certain entities of law mainly concerning the exercise of publicpower powers, realization and protection of subjective public rights and freedoms, satisfaction of public interests and regulated by a complex of public-legal norms of different branches of law ${ }^{11}$. In the theory of law, public law is defined as a subsystem of law, which consists of norms governing relations related to the exercise of functions of public authority in the sphere of the interests of the state and local self-government through the imperative method of legal regulation. Public interest is the general public interest recognized by the state, which relies on its support and legal protection ${ }^{12}$.

Therefore, the legal meaning of the category "public" is revealed in legal phenomena that do not involve individualization and do not relate to private (personal) interest. According to the modern content of public administration, this category is close to the content of the category "public administration". Against this background, the content of the terminology of the term "public administration" needs further scientific analysis and clarification.

The following requirements for scientific terms should be taken into account when conducting further research to clarify the term "public administration":

11 Великий енциклопедичний юридичний словник/ За ред.. акад.. НАН України Ю. С. Шемшученка. - 2-ге вид., переробл. і доповн. - К.: Вид-во "Юридична думка", 2012. $-1020 \mathrm{c}$.

12 Теорія держави i права: підручник/ О. В. Петришин, С. П. Погребняк, В. С. Смородинський та ін.; за ред. О. В. Петришина. - Х.: Право, 2015. - 368 с. 
- should denote concepts that are the result of direct knowledge of state and legal reality;

- should reflect social realities;

- their appearance, change or removal from circulation should be dictated by the real needs of the practice;

- the legislation should stipulate those scientific terms that are conventional in nature, they are called doctrinal terms ${ }^{13}$.

If you apply the above requirements to the term "public administration", then there are at least two questions. First, the introduction of a new term requires a well-grounded critique of pre-existing terminology. Secondly, it is necessary to prove the objective nature of the need to introduce a new term in the presence of existing and elaborated in the doctrine of administrative law.

Next after the logic of scientific analysis is the question of the relationship between the terms "public administration" and "state regulation", for analysis of which an approach was proposed, which involves the use of the general concept of "organization" (or "organizational activity"). In this case, the concept of "organization" is not limited to considering it as "organizational activity", but also considered as the organization of a system of authorities that exercise their authority to achieve specific goals in certain areas of public administration and regulation. Revealing the relation between these concepts in the example of tourism industry management, the wider meaning of the term "regulation" is defined. Thus, the state administration covers the type of activity of the state, the content of which is to exert organizational influence on a certain branch (in fact - the entity of public administration) by using the powers of executive authorities and local self-government bodies through the implementation of laws, implementation of administrative functions, ensuring the implementation of public policy. State regulation is a set of methods of public administration, which provides for a system of measures of legislative, executive and control nature and is carried out by state bodies in a certain area in order to stabilize its functioning ${ }^{14}$.

In this approach, administrative oversight goes beyond public administration and state regulation, given that this type of state activity also applies to the exercise of jurisdiction by authorized entities. Therefore, the term "administrative activity" is more consistent with the nature and content of administrative oversight.

13 Любченко М. І. Юридична термінологія: поняття, особливості, види: монографія / М. І. Любченко. - Х.: ТОВ “Видавництво права людини”, 2015. - 280 с.

14 Чан Тхуи Ван. Организационно-правовое обеспечение туризма во Вьетнаме (сравнительный анализ с Украиной): дис.к.ю.н. 12.00.07/ Чан Тхуи Ван/ Инстиут государства и права им. В. М. Корецкого НАН Украины. - К., 2016. - 206 с. 


\section{Place of administrative supervision in the executive branch}

Determining the place of administrative oversight in the executive branch, it is expedient to highlight the approach of Salishcheva N.G. regarding the essence of state-power powers, which are considered in the context of federal executive bodies. Thus, state-governmental powers of federal executive bodies are proposed to be considered as:

- the legislative powers that enable the relevant body (government, ministry) to establish certain rules, as well as standards, normative requirements, prohibitions, administrative regimes, etc.;

- enforcement powers, that is, the right to carry out certain legal actions, to adopt normative legal acts, to resolve specific conflicts between entities of administrative activity, to carry out permitting functions, to provide administrative (state) services;

- law enforcement powers, ie the right to ensure legality and discipline, to carry out administrative and jurisdictional activities, to apply measures of administrative coercion, administrative responsibility ${ }^{15}$.

Approach of Salischevoyi N.G. may be taken into consideration with certain reservations. Thus, the scientist emphasizes the law enforcement nature of the powers of the executive authorities, which, although it is acceptable for determining the nature of state-power powers, nevertheless reflects one aspect of the functioning of the executive authorities.

Academician Averianov V.B. singled out the activities of bodies that are not administrative in essence: applying to the citizens measures of administrative coercion, including administrative penalties; extrajudicial protection of violated rights and freedoms of citizens (in order of administrative appeal); consideration and resolution of administrative cases at the request of individuals, including the provision of various administrative (management) services in the form of permit-registration and other such actions; making binding decisions on individuals in the process of addressing so-called "public needs" (such as land acquisition, construction of roads, bridges, etc.). The scientist emphasized that the executive power is realized not only in the form of state administration, but also in various other forms of state activity, which is entity to regulation by administrative law ${ }^{16}$.

Scientific approach of academician Averianov V.B. reveals the essence of the activity of executive bodies as a multidimensional one, which is not limited to purely power-organizing and proper administrative functions.

15 Административное право России: курс лекций / К. С. Бельский [и др.]; под. ред. Н. Ю. Хаманевой. - М.: ТК Велби, Изд-во Проспект, 2008. - 704 с.

16 Авер'янов В. Б. Вибрані наукові праці под ред. Ю. С. Шемшученко, О. Ф. Андрійко. - К.: Інст-т держави і права ім. В. М. Корецького НАН України, 2011. $448 \mathrm{c}$. 
However, if we consider the opinion of Salishcheva N.G. regarding the essence of state-governmental authority, it is possible to point out the expediency of attributing the activity of the executive authorities to the application of measures of administrative coercion to law enforcement activity, which is aimed at ensuring legality and discipline.

From the above scientific controversy on the nature and content of the basic categories of science of administrative law, we can distinguish the established position, the content of which there are no fundamental contradictions - the provision of law enforcement as one of the main functional types of state (Averyanov V.B.) and the main organic connection of the functions of executive bodies with state-power powers (Averyanov V.B.) ${ }^{17}$. In this approach, administrative oversight should be considered as one of the varieties of the basic functional type of lawenforcement activity, which has its own purpose and object within the general direction of the administrative (executive) activity of the executive power holders, which advocates the realization of citizens' constitutional rights and protection of their rights. and freedoms.

The executive holder is the executive body. The part of the state apparatus (organization) is defined by him, and this state apparatus has its own structure and staff, territorial scope of activity, is formed in the statutory or other legal acts, in the manner and within the limits of the envisaged competence, performs on behalf of the state the functions of public administration in economic, social -cultural, administrative-political spheres of public life ${ }^{18}$. Similar to the list of features (traits) of the executive authority, and therefore the essence of the definition of the corresponding concept is provided by Chetverikov V.S. ${ }^{19}$.

Such a definition is complemented by the inclusion in it of the features (features) of structuring by departments and positions occupied by public servants, and by the constitution and laws of Ukraine in the system of bodies of executive power. The body of executive power is an organizationally independent element of the state apparatus (mechanism of the state), which is endowed with a clearly defined scope of powers (competence) in accordance with the tasks and functions assigned to it, consists of structural units and

17 Адміністративне право України. Академічний курс: Підруч.: У двох томах: Т. 1. Загальна частина / Ред. колегія: В. Б. Авер'янов (голова) та ін. - К.: ТОВ “Видавництво “Юридична думка", 2007. - 592 с.

18 Адміністративне право [Текст]: підручник/ Ю. П. Битяк (кер.авт.кол.), В. М. Гаращук, В. В. Богуцький та ін. ; за заг.ред. Ю. П. Битяка, В. М. Гаращука, В. В. Зуй. - Х. : Право, 2010. - 624 с.

${ }_{19}$ Четвериков В. С. Административное право: ученик/ В. С. Четвериков. - М.: Эксмо, 2010. -608 c. 
positions occupied by civil servants, and is classified by the Constitution of Ukraine to the system of executive authorities.

Scientists also identify the following attributes of the executive power: the creation for the purpose of direct implementation of a specific type of state activity; performance of activities characterized by a clearly defined state orientation, goals, objectives and functions; implementation of activities using state-defined methods and forms. An important feature of the executive authority is the establishment of its legal form of legal personality, which gives the right to enter and participate in certain legal relationships.

Summarizing of scientific provisions mentioned above allows us to distinguish the following features (features) of the executive authority:

- is part of the state apparatus and is referred to by the Constitution and laws of Ukraine as a system of executive bodies;

- has legal status, acts as a holder of state-power powers, which he implements in connection with the implementation of public administration in the socio-economic and other spheres of society;

- has the legal form of a legal entity;

- created for the purpose of direct implementation of a specific type of state activity using state-defined methods and forms;

- within the system of bodies of executive power is endowed with operational autonomy, which is expressed in entities of authority, rights, duties, territorial limits of activity of each individual body;

- the activity is subordinate, executive and administrative in nature;

- it is structured by units and positions occupied by civil servants;

- financing of activities is carried out from the state budget.

The body of executive power is appropriate to name the part of the state apparatus, structured according to the units and positions occupied by civil servants, created with the purpose of direct realization of a specific type of state activity by means of the state-defined methods and forms and referred to by the Constitution and laws of Ukraine in the system of bodies of executive power.

Characterizing the executive authorities as entities of administrative law, it should be pointed out to the well-established scientific opinion that the entity of administrative law can be only the one that has the potential ability to enter into legal relations. At the same time, the proposed approach to the definition of the entity of administrative law does not actually contradict the existing developments. This determines the paramount role in establishing the content of the administrative-legal relations of their parties (entities). Such parties are the entities of administrative law, they are the holders of the administrative and legal norms of rights and obligations that are capable of exercising these rights, and the assigned duties. In this way, not only the potential ability to be 
the holder of administrative and legal powers, but also the ability to exercise these powers is actually indicated.

Based on the information mentioned above, it is advisable to provide a narrow and wide understanding of the category of "entity of administrative law". In the wide, this category covers not only the potential to enter into legal relationships, but also the exercise of the rights and obligations conferred by an administrative rule. In a narrow sense, the category of "entity of administrative law" encompasses the potential for legal capacity.

The primacy of the wide view of the essence of the category "entity of administrative law" allows the application of the category of "entity" to all participants of administrative and legal relations, regardless of whether they are potential participants, or actually participate in such legal relations.

In this approach, it is possible to formulate the concept of executive authority as an entity of relations in the field of administrative oversight.

The executive body as the entity of relations in the field of administrative supervision - part of the state apparatus, empowered with the administrative norms of rights and responsibilities in the relations with the administrative supervision as a separate type of state-governmental, executive activity, thereby generating such relations, in who appear to be a potential or a real party.

The signs of the executive authority as the entity of relations in the field of administrative supervision are derived from the most essential features of the executive authority, identified by scientists. The difference lies in the specific nature of the relations in the field of administrative supervision as a stategovernmental activity aimed at establishing the conformity of the state of the supervised object with the current legislation without interfering with its activity. Such specificity determines the content of the activity of the executive authorities in the sphere of administrative supervision, the competence in the relevant relations and the limits of its implementation. The characteristics of the executive branch of the legal supervisory relationship should also be taken into account.

Therefore, the most essential features of an executive authority as a legal entity in the area of administrative oversight should be identified as follows:

- is a legal entity separated by legal status;

- acts on behalf of the state and for the performance of functions of the state;

- the administrative capacity of a body of executive power is defined by legal status as a holder of state-power powers in connection with the exercise of administrative supervision;

- has administrative legal personality, defined by legislative acts, the rules of which regulate relations in the exercise of administrative supervision; 
- realizes administrative legal personality within the limits of carrying out administrative supervision as administrative activity of special character;

- activities aimed at ensuring legality and discipline;

- predominantly endowed with the power to resolve a case-by-case and to make a legally binding decision, binding on the addressees of the order;

- the decision taken by the executive authority on the consequences of administrative supervision, causes for the addressees of the prescriptions certain restrictions, stipulated by the legal norm.

Characterizing the executive authorities as entities of administrative oversight, it is necessary to point out their main feature as the presence of state-power powers.

In particular, Bevzenko V.M. characterizes the content of a power management function as a criterion for determining the entity of power, substantiates the relevant category, establishes the types of entities and the form of their participation in administrative justice. Based on the existing scientific achievements of scientists determines the following features of managerial functions: a) it is one of the types (directions) of a conscious, volitional, active, purposeful activity of a public authority, local selfgovernment body, their official or official person, other authorized entity; b) it is part of the content of management activity, relatively independent and homogeneous; c) power-organizing, regulatory influence, which in the established forms and methods and in a certain procedure is exercised by authorized entities, expresses the power-organizational nature of management, and the purpose of influence, in general, is to streamline a certain type of social relations, bringing them in line with the needs of society, the state, the focus of management functions on ensuring the vital needs of the management object; d) the presence of each function of a managerial function, the performance of which ensures the performance of the current task, the exercise of a legal duty, and therefore the management function is a kind of means, a way of exercising the rights and duties entrusted to an authorized entity; e) establishing by law the types, content and procedures of performing management functions; f) the exercise of managerial functions solely within the limits of the public powers conferred; g) identification of the content and procedure for the implementation of a specific managerial function in the development, drafting and execution of various regulatory, individual and other acts, as well as the manifestation of management functions in the exercise of physical-mental, procedural nature - coordination of joint actions, verification, introduction to databases, etc.; h) the implementation of managerial functions in the relationship between the entity and the object of management; i) the logical connection between the previous performance of administrative and subsequent functions, the interconnection and 
interdependence of functions with each other, the formation of their implementation of continuous, long, heterogeneous procedural activities of an authorized entity (state authority, local government, their official, another entity); j) ensuring the exercise of the administrative function and its effectiveness by the coercive power of the state, on whose behalf the relevant authorized entity acts.

The managerial function is the purposeful, procedural, by-law activity of an authorized entity (state authority, local self-government body, their official or official person, other entity), which should ensure the fulfillment of its tasks by the relevant entity, meeting the needs of society or the state. The list of basic management functions includes: forecasting, planning, organization, coordination, control, accounting, motivation ${ }^{20}$.

Scientific approach Bevzenko V.M. is built on the legal essence of the category of "functions of public administration", which allows to take into account the orderly content of management activities and the established approach to determining the essence of management. In the development of existing work, the researcher proposes to introduce a legal procedure under which the managerial function should be implemented. Taking into account this theoretical shortcoming allows you to: firstly, to apply the theoretical model of the formed features of the managerial function to the analyzed legal phenomena in order to distinguish similar functions and, secondly, to establish the existence of legal procedures for the implementation of the respective functions. In this case, the proposed Bevzenko's V.M. theoretical construction of "public function" is wide and covers all the functions entrusted to entities that fall into the category of public: public authorities, local governments, public organizations. According to information mentioned above, it is difficult to establish the feasibility of a theoretical construction with such a wide content.

The systematic and dynamic content of the content of the term "authority" determines the need to analyze the category of "authority", which suggested the use of Yampolska Ts.A. In her view, authority should be considered from the standpoint of the status of a state body. This approach does not contradict the provisions formulated by Tykhomirov Yu., who indicated that the power of the state actually consists of a number of inextricably linked elements, among which the most important are the following:

a) the issuance of statutes by the state - legal acts that are binding on all citizens and officials;

20 Бевзенко В. М. Участь в адміністративному судочинстві суб'єктів владних повноважень: правові засади, підстави та форми: монографія / В. М. Бевзенко. - К. : Прецедент, 2010. - 475 с. 
b) protection of these orders from violations by the coercive power of the state;

c) ensuring the enforcement of orders by education, persuasion;

d) the material support of the execution of state orders through the disposal of a single state property fund ${ }^{21}$.

Proposed elements by Tykhomyrov of power are the basis for establishing meaningful characteristics of power, such as state orders issued within the competence, binding and protected by the coercive power of the state.

The substantive characteristics of ownership substantiated above are also characteristic of administrative supervision.

Haraschuk V.M. noted correctly, that in the system of control and supervisory activity, the executive authorities have the most essential powers. This is due to the fact that the system of designated bodies is created by the state for the day-to-day (continuous) management activities, of which, as already noted, is oversight. The management process constantly requires, in addition to scientific forecasting, the correction and correction of the "course", the finding and elimination of deficiencies that occur periodically along the way. Each executive body, its officials, within the limits of their powers, control the implementation of the decisions taken, the observance of the legislation in the activities of a particular system, individual structural unit or industry. Such control may relate to both the internal aspects of the system and its external relations ${ }^{22}$.

\section{CONCLUSIONS}

The analysis of scientific views on the definition of categories, which denote the functional and subjective constituent of the executive power, allowed to form an approach on the essence of the executive power and the place of administrative supervision in the executive power.

Pointing to the essence of executive power it should be based on a scientific approach established in the science of administrative law, which provides for its disclosure in the light of the principle of separation of state power as one of the functional types of activity of the state - the implementation of laws by authorized entities - holders of executive power. The relevant activity is defined as administrative (executive). Administrative supervision is one of the varieties of the specified functional activity of the

${ }^{21}$ Тихомиров Ю. А. Теория компетенции. - М.: Юринформцентр, 2001. - 355 с.

22 Гаращук В. М. Теоретико-правові проблеми контролю та нагляду у державному управлінні : автореф. дис.. на здобуття наук. ступеня доктора юридичних наук : спец. 12.00.07 - теорія управління; адміністративне право і процес; фінансове право / Володимир Миколайович Гаращук ; Національна юридична академія України ім.. Ярослава Мудрого. Харків, 2003. - 35 с. 
state, which has its own purpose and object within the general orientation of the administrative (executive) activity of the holders of executive power.

Administrative supervision should be defined as part of the executive activity of the authorized bodies of the state executive power, other entities (their officials), empowered with the administrative legal authority to establish the extent and degree of compliance of the activity of the entity to administrative supervision to the current legislation, and also guaranteeing safety in certain spheres of life of the population, which is a relatively separate, power-organizing, implementation procedures established by current legislation. Administrative oversight procedures include the development, drafting of individual legal acts, and the taking of organizational actions in order to fulfill the tasks assigned by the current legislation to an entity, authorized to carry out administrative supervision. Administrative enforcement is ensured by the coercive power of the State on whose behalf the relevant authorized entity acts.

\section{SUMMARY}

The most essential features of the executive authority as the entity of legal relations in the field of administrative supervision are: separated by the legal status of the entity of administrative and legal relations; acts on behalf of the state and performs the functions of the state; the administrative capacity of a body of executive power is defined by legal status as a holder of state-power powers in connection with the exercise of administrative supervision; has administrative legal personality, defined by legislative acts, the rules of which regulate relations in the exercise of administrative supervision; realizes administrative legal personality within the limits of carrying out administrative supervision as administrative activity of special character; aimed at ensuring legality and discipline; predominantly endowed with the power to resolve an individual case and make a legally binding decision, binding on the addressees of the order; such a decision taken by an executive authority following the effects of administrative oversight causes certain recipients of the injunctions prescribed by the rule of law. On the basis of signs of administrative supervision, determinations of distinction between control and supervision in methodological and normative values the concept of administrative supervision of executive bodies is set forth. Leaning against approach of the systems, expediency of description of subjects of administrative supervision is well proven in three aspects: structuralfunctional, synergetics and responsible. Classification of subjects of administrative supervision is offered not only on the sign of competence but also after character of the article of realization. The concept of principles of administrative supervision is reasonable, general and special principles are distinguished. Systematization of methods of administrative activity is conducted in relation to realization of supervision National Policy. 


\section{REFERENCES}

1. Виконавча влада i адміністративне право / За заг.ред. В. Б. Авер'янова. - К.: Видавничий Дім “Ін Юре”, 2002. - 668 с.

2. Денисова А. В. Сущность и содержание базовых категорий административного права: отдельные проблемы определения / А. В. Денисова // Legea si Viata. - 2017. - № 3/2 (303). - С. 57-60.

3. Золотарьова Н. I. Співвідношення виконавчої влади та адміністративної діяльності / Н. І. Золотарьова // Вісник Національного технічного університету “КПІ”. - 2011. - № 1 (9). - С. 45-54.

4. Гробова В. П. Адміністративний аспект державного управління / В. П. Гробова // Актуальные проблемы права : теория и практика. Сборник научных трудов. - 2010. - № 18. - С. 298-304.

5. Державне управління : навч. посіб. / [Мельник А. Ф., Оболенський О. Ю., Васіна А. Ю., Гордієнко Л. Ю. та ін.] ; під ред. А. Ф. Мельник. - К. : Знання-Прес, 2003. - 343 с.

6. Синкова О. М. Підзвітність в системі органів виконавчої влади: організаційно-правові проблеми: дис..д.ю.н. 12.00.07 / Синкова Олена Михайлівна/ Інститут держави і права ім.. В. М. Корецького НАН України. - К., 2011. - 400 с.

7. Рябченко О.П. Концептуальні проблеми застосування диспозитивного методу публічно-правового регулювання відносин у сфері економіки / О. П. Рябченко: наукова доповідь. - К.: Логос, 2013. $-40 \mathrm{c}$.

8. Денисова А. В. Сутність адміністративної діяльності щодо здійснення нагляду органами виконавчої влади та їі місце у виконавчій владі / А. В. Денисова // Актуальні проблеми держави і права. - 2017. Випуск 79. - С. 46-50.

9. Курс адміністративного права України: підручник / В. К. Колпаков, О. В. Кузьменко, І. Д. Пастух, В. Д. Сущенко [та ін.] / за ред. В. В. Коваленка. - К.: Юрінком Інтер, 2012. - 808 с.

10. Вітвіцький С. С. Контроль діяльності публічної адміністрації в Україні: теорія i практика [монографія] / С. С. Вітвіцький. Дніпропетровськ: Дніпропетровський державний університет внутрішніх справ, 2015. - 362 с.

11. Великий енциклопедичний юридичний словник / За ред.. акад.. НАН України Ю. С. Шемшученка. - 2-ге вид., переробл. і доповн. - К.: Вид-во “Юридична думка", 2012. - 1020 с.

12. Теорія держави i права: підручник / О.В. Петришин, С. П. Погребняк, В. С. Смородинський та ін.; за ред. О. В. Петришина. Х.: Право, 2015. -368 с. 
13. Любченко М. І. Юридична термінологія: поняття, особливості, види: монографія / М. І. Любченко. - Х.: ТОВ "Видавництво права людини", 2015. - 280 с.

14. Чан Тхуи Ван. Организационно-правовое обеспечение туризма во Вьетнаме (сравнительный анализ с Украиной): дис.к.ю.н. 12.00.07 / Чан Тхуи Ван / Инстиут государства и права им. В. М. Корецкого НАН Украины. - К., 2016. - 206 с.

15. Административное право России: курс лекций / К. С. Бельский [и др.]; под. ред. Н. Ю. Хаманевой. - М.: ТК Велби, Изд-во Проспект, 2008. - 704 c.

16. Авер'янов В. Б. Вибрані наукові праці / [ред. Ю. С. Шемшученко, О. Ф. Андрійко]. - К.: Інст-т держави і права ім. В. М. Корецького НАН України, 2011. - 448 с.

17. Адміністративне право України. Академічний курс: Підруч.: У двох томах: Том 1. Загальна частина / Ред. колегія: В. Б. Авер'янов (голова) та ін. - К.: ТОВ “Видавництво “Юридична думка", 2007. - 592 с.

18. Адміністративне право [Текст] : підручник / Ю. П. Битяк (кер.авт.кол.), В. М. Гаращук, В. В. Богуцький та ін. ; за заг.ред. Ю. П. Битяка, В. М. Гаращука, В. В. Зуй. - Х. : Право, 2010. - 624 с.

19. Четвериков В. С. Административное право: ученик / В. С. Четвериков. - М.: Эксмо, 2010. -608 с.

20. Бевзенко В. М. Участь в адміністративному судочинстві суб'єктів владних повноважень: правові засади, підстави та форми: монографія / В. М. Бевзенко. - К. : Прецедент, 2010. -475 с.

21. Тихомиров Ю. А. Теория компетенции. - М.: Юринформцентр, 2001. $-355 \mathrm{c}$.

22. Гаращук В. М. Теоретико-правові проблеми контролю та нагляду у державному управлінні : автореф. дис.. на здобуття наук. ступеня доктора юридичних наук : спец. 12.00.07 - теорія управління; адміністративне право i процес; фінансове право / Володимир Миколайович Гаращук ; Національна юридична академія України ім. Ярослава Мудрого. - Харків, 2003. - 35 с.

\section{Information about the author:}

Denysova A. V.,

Doctor of Law, Associate Professor, Head of the Department of Administrative Law and Administrative Process, Odessa State University of Internal Affairs 1, Uspenska str., Odessa, 65000, Ukraine 